\title{
WPS3633
}

\section{INVESTMENT AND SAVING IN CHINA}

\author{
Louis Kuijs *
}

\author{
The World Bank Office, Beijing, China \\ East Asia Pacific Poverty Reduction and Economic Management (EASPR)
}

Keywords: Investment; saving; financing; demographics, corporate governance, China.

JEL Classification: E21, E22, G21, H50, O16.

World Bank Policy Research Working Paper 3633, June 2005

The Policy Research Working Paper Series disseminates the findings of work in progress to encourage the exchange of ideas about development issues. An objective of the series is to get the findings out quickly, even if the presentations are less than fully polished. The papers carry the names of the authors and should be cited accordingly. The findings, interpretations, and conclusions expressed in this paper are entirely those of the authors. They do not necessarily represent the view of the World Bank, its Executive Directors, or the countries they represent. Policy Research Working Papers are available online at http://econ.worldbank.org.

* I thank Bert Hofman for encouragement and comments, and Homi Kharas and Tao Wang for comments on an earlier draft. I also thank Pieter Bottelier, whose comments will be reflected in a revised version.

Address for correspondence:akuijs@worldbank.org. 


\section{Introduction}

With China's investment and saving high-in historical context and compared to other countries-questions on investment and saving continue to arouse the interest of policymakers and researchers. However, knowledge about the underlying patterns of investment and saving is limited. This paper attempts to answer the following questions. What are the factors driving China's high investment? How is saving channeled into investment? In particular, how is enterprise investment financed, and what are the roles of the domestic banking sector, enterprise saving, and the government?

Answers to these questions are important for several reasons. First, they inform the current debate on the types of risks and policy challenges stemming from China's high investment, including on what policies are needed to mitigate risks and improve the efficiency of capital allocation. Second, they facilitate the understanding of China's pattern of growth. High investment and saving are key features of China's pattern of growth. A better understanding of their determinants could improve the understanding of the pattern of growth; its sustainability; and medium and long-term prospects. Third, they help identify the policy implications of the projected saving and investment developments, also in light of identified tensions and the intended change in the policy stance, including the planned shift in government spending from investment to social spending and the increased role of private consumption.

To answer these questions, the paper analyzes sectoral trends in investment and saving and the resulting sectoral saving-investment balances over time and relates them to cyclical and structural developments, to better interpret current developments. It also compares these trends to those in other countries to identify China's special features.

The paper uses - apparently for the first time-time series data from the Flow of Funds (FoF) from the national accounts. ${ }^{1}$ The advantage of these data is that they reflect financial flows between sectors. Moreover, the "above the line” flow data are mapped with "below the line" data on financing. The conclusions based on this data are verified by looking at data from other sources, including from the financial sector, on the financing of investment from the Statistical Yearbook (SYB), and the household survey. ${ }^{2}$

This paper does not look into potential problems with data on investment and GDP, reflecting a belief that, in addition to any data problems-most of which are pertinent in other countries too- there are economic explanations behind the developments on investment and saving in China. ${ }^{3}$

\footnotetext{
${ }^{1}$ The FoF accounts show for households, enterprises, the government, and the "rest of the world" the sources and uses of financial resources. The "above the line" flows show the composition of income, consumption and saving, physical investment, and the resulting net external financing. The "below the line" flows show how each sector's net external financial balance is invested and/or financed.

${ }^{2}$ The FoF data is only available up until 2001, and, for some parts, 2002. Some estimates are made for 2002 and 2003, but these are meant to be only indicative. For instance, household saving is estimated using the year-on-year change in household saving from the household survey.

${ }^{3}$ Data on Fixed Asset Investment in China (FAI) includes land sales. National accounts data on Gross Capital Formation (GCF), which does not include such sales, is better comparable internationally.
} 
We find that since the early 1990s investment by households and direct investment by the government have been relatively steady at levels comparable to other countries, while investment by the enterprise sector distinguishes China from other countries and explains most of the variation of China's total investment over time. We also find that high household saving explains only part of the difference in total saving between China and other countries; the rest is explained by high saving of the government and enterprises, the latter particularly in recent years, as profitability has improved. Net external financing of enterprise investment-from the banking sector and via net foreign direct investment (FDI) - is high compared to other countries but, at about one-third, constitutes only a modest part of enterprise investment.

High government saving is the result of a policy favoring government-financed investment over government consumption. Reasons for relatively high saving by enterprises include a high share of capital-intensive industry in GDP and a traditional policy of low (or no) dividends.

These findings lead to three sets of policy implications. First, the financing patterns indicate a lower degree of bank financing to enterprises and associated financial sector exposure than is usually thought. By the same token, though, against the background of concerns about suboptimal allocation of capital, the high degree of financing by retained earnings and government transfers bring to the fore issues of (corporate) governance and dividend policy, as well as of transparency and accountability of public funds. Second, the planned shift in government spending from investment toward social spending and the increased role of private consumption can be brought about by reducing the high share of government revenue traditionally devoted to investment and changing the policy framework away from the promotion of capital-intensive industry. Third, saving is projected to decline in the long term, with the speed depending on policy adjustments.

\section{A. Findings in existing literature about saving in China}

Domestic saving finances the bulk of any country's investment. Questions about levels of investment are therefore closely linked to questions on saving. The theoretical literature on the determinants of saving is rooted in consumption theory and, consequently, largely centers on factors affecting households. Loayza, Schmidt-Hebbel, and Servén (2000) provide an overview of empirical studies in this area in developed and developing countries. Their own cross country empirical work finds that private sector and national savings are affected by:

- The level of development (per capita income), with the influence of per capita income larger in developing countries;

- Economic growth, with much of the causation running from growth to saving;

- Fiscal policy, with its impact on national savings typically only partly offset by responses in private saving;

However, as this is only available on an annual basis, FAI data is used regularly. Although the data used in this paper is on GCF, there may still be issues in international comparisons. In addition, China's GDP data is often considered to be underestimated, due to the limited capture of rapidly developing sectors, although this is true for many countries. 
- Pension reform, with direct short-term effects depending on the financing of the transition deficits and long term effects likely dominated by labor market effects;

- Financial liberalization, with the impact on saving of interest liberalization mixed, but a strong effect from expanding the supply of credit to people that had been credit-constrained; and

- Demographics, with an increase in the share of young or elderly dependents in the population tending to reduce private saving — by 1 percentage point (pp) for a 3.5 percentage point increase in the young age dependency ratio, and $2 \mathrm{pp}$ for a similar increase in the old age dependency ratio;

as well as by external borrowing and foreign aid, and uncertainty.

China's national saving rate is high relative to international experience, even after controlling for these determinants of saving. Kraay (2000) found, based on a crosscountry regression using the above set of variables, that China's high national saving rate — on average 37 percent between 1978 and 1995, compared to an international average of almost 21 percent—can be partly explained by high growth and, to a lesser extent, favorable demographics. However, China's national saving rate was 10 percentage points higher than what would be expected based on China's characteristics.

The increase in China's household saving ratio to a high level is well-documented, and largely explained. Kraay (2000) presents data on saving based on the household survey and on wealth data. He notes that prior to the reforms, high saving "were engineered by state fiat", via administered relative prices that ensured high profits in state-owned enterprises, which then could be directed to the state's investment priorities. Household saving were low in the pre-reform area. Subsequent to the reform, public saving has diminished, whereas rising household incomes have made household saving newly prominent, "with households contributing between a quarter and half of total saving." 4

Modigliani and Cao (2004) attribute China’s high household saving to increases in growth and changing demographics. Their saving data is constructed from changes in personal wealth using asset data. ${ }^{5,6}$ Their (single country, time series) empirical analysis suggests that household saving has risen due to (i) the economic reforms since the end1970s, and the increase in growth and growth prospects they generated; as well as (ii) the introduction of the one-child policy at around the same time, which led to a gradual increase in the ratio of employment to total population and undermined the traditional

\footnotetext{
${ }^{4}$ Such observations on the relative importance of household saving, and the implied saving by enterprises and the government, do not seem to have featured in most subsequent discussions on saving in China.

${ }^{5}$ They test the validity of the life cycle hypothesis (LCH) of saving on China. The LCH stresses intertemporal considerations in saving decisions. It asserts that the saving rate largely depends on economic growth (and growth prospects) and the demographic structure of a country (in particular, the relation between the working and the non-working population), rather than the level of income.

${ }^{6}$ Using data from the SYB, they calculate saving as: the change in (currency + deposits) + new issuance of bonds + individual investment in fixed assets. Their data indicates that the household saving rate was very low (around 5 percent) until the reforms started in 1978. The household saving rate subsequently rose rapidly, peaking at over 33 percent in 1994, after which it declined gradually to 24 percent in 2000.
} 
role of the family in providing old-age support. ${ }^{7}$ They also note that the very low saving rate prior to1978 calls into question “cultural” explanations of China's high saving rate.

As elaborated in this paper, analysis of sectoral data explains why the consensus set of factors discussed above-largely centered on households-cannot fully explain China's high national saving ratio, even though the level and movement of China's household saving ratio can largely be explained. This is because most of the difference in national saving rate between China and other countries is explained by saving outside the household sector: by enterprises and the government (see text table). The paper adds to the existing literature by exploring the sectoral patterns, focusing on the patterns of enterprise and government saving.

Text table. China: Comparing Saving with Other Countries.1/

(in percent of GDP)

\begin{tabular}{lrrrrrr} 
& China & $\begin{array}{c}\text { United } \\
\text { States }\end{array}$ & France & Japan & Korea & Mexico \\
\hline Total Domestic Savings & 42.5 & 14.3 & 20.7 & 25.5 & 31.0 & 20.8 \\
& & & & & & \\
Difference China-others & 28.2 & 21.8 & 17.0 & 11.5 & 21.7 \\
$\begin{array}{l}\text { due to: } \\
\quad \text { Household saving }\end{array}$ & 11.8 & 5.8 & 8.4 & 12.1 & 8.6 \\
$\quad$ Enterprise saving & 8.6 & 9.4 & -0.5 & 4.1 & 8.3 \\
$\quad$ Government saving & 7.9 & 6.7 & 9.2 & -4.7 & 4.8
\end{tabular}

Source: NBS (national accounts), via CEIC, and OECD National Accounts.

Data for China is for 2003, for Mexico for 2001, and for other countries for 2002.

1/ For details, see Table 2.

\section{B. Investment and Saving (1990-2003)}

\section{Investment}

Investment has been high throughout this period, with household and government investment stable at rates comparable to other countries. Enterprise investment, ranging between 27 and 35 percent of GDP, makes China’s investment high.

Since the mid-1980s, (total) investment in China has been high. ${ }^{8}$ As a share of GDP, it peaked at 43.3 percent of GDP in 1993 during the height of the previous economic cycle (Table 1 and Figure 1). The cyclical slowdown in investment thereafter was moderate, with the investment to GDP ratio reaching a low of 36.3 percent in 2000 (1999 was the

\footnotetext{
${ }^{7}$ Kraay, using provincial level data, finds only little correlation between growth and saving, and positive correlation between saving rates and per capita income.

${ }^{8}$ The investment data used in this paper is annual gross capital formation from the national accounts, which is to be distinguished from the higher-frequency fixed asset investment data.
} 
trough of the cycle in terms of GDP growth). Since then, the ratio increased to 43.8 percent of GDP in 2003 and is estimated to have grown to an even higher share in 2004.

Up until the end of the 1990s investment in inventories was substantial. According to the national accounts, it reached a remarkable 10 percent of GDP in 1989, and declined gradually thereafter. In addition to possibly indicating data problems, these data indicate the build up of inventories produced in the absence of market economy signals. To the extent that the decomposition of investment - in fixed investment and change in inventories - has been meaningful for the whole data period, gross fixed investment has been subject to a trend increase since the early 1990s (Figure 1).

Figure 1. China: Investment (percent of GDP)

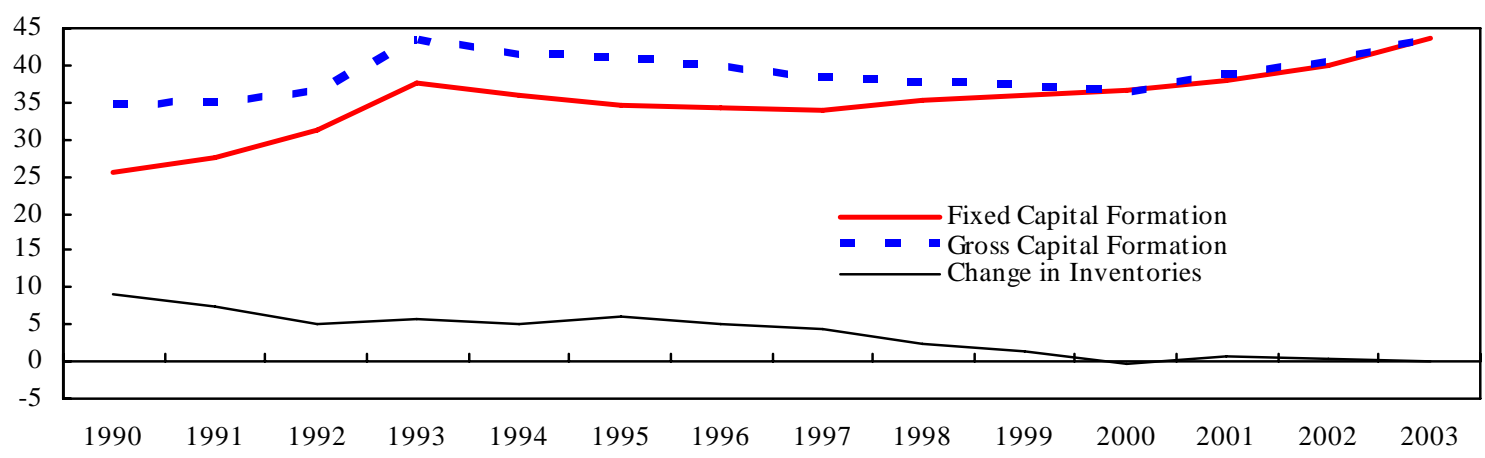

Source: NBS, and staff estimates.

Investment by households and (direct) investment by the government has been relatively steady at levels comparable to other countries. Investment by households, largely residential, has been 5-6 percent of GDP since the early 1990s; in recent years it has been increasing, to an estimated 6.7 percent in 2003 (and further in 2004) (Figure 2, upper panel). Since the early 1990s, investment by the government has been around 3-4 percent of GDP. As shown below (see Table 2), household and government investment are in the range found for other countries.

Investment by the enterprise sector distinguishes China from other countries, and explains most of the cyclical variation in investment. Enterprise capital formation reached a peak of 35.5 percent of GDP in 1993, at the height of the previous cycle. As a ratio of GDP it declined thereafter, to a low of 27.3 percent of GDP in 2000. During the recent cyclical upturn it increased to an estimated 33.8 percent of GDP in 2003. 
Figure 2. China: Sectoral Saving and Investment, 1990-2003 1/

Investment (percent of GDP)

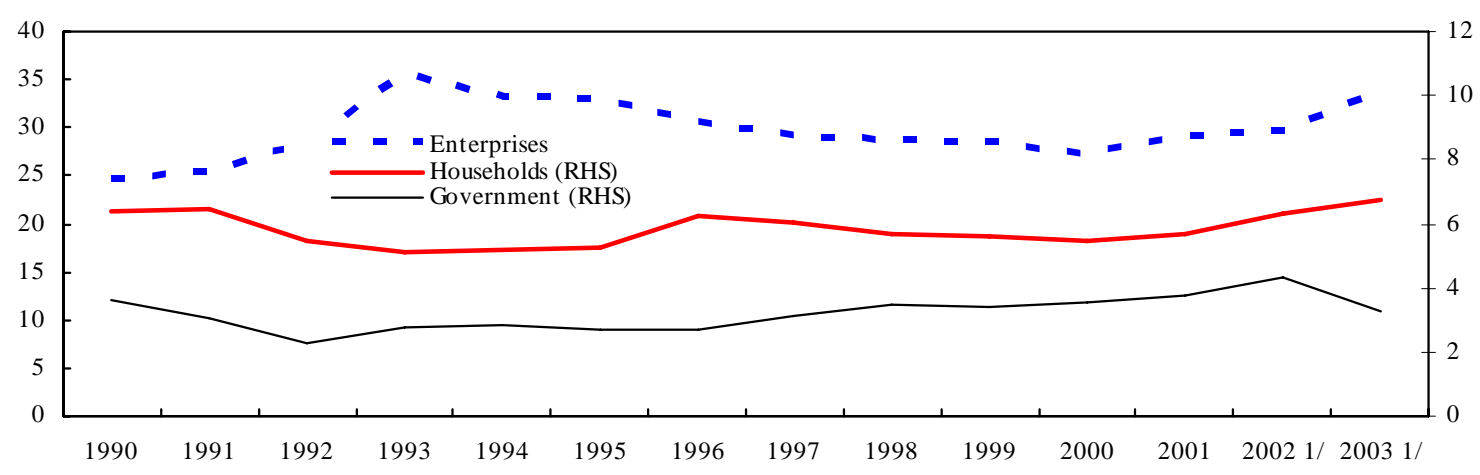

Saving (percent of GDP)

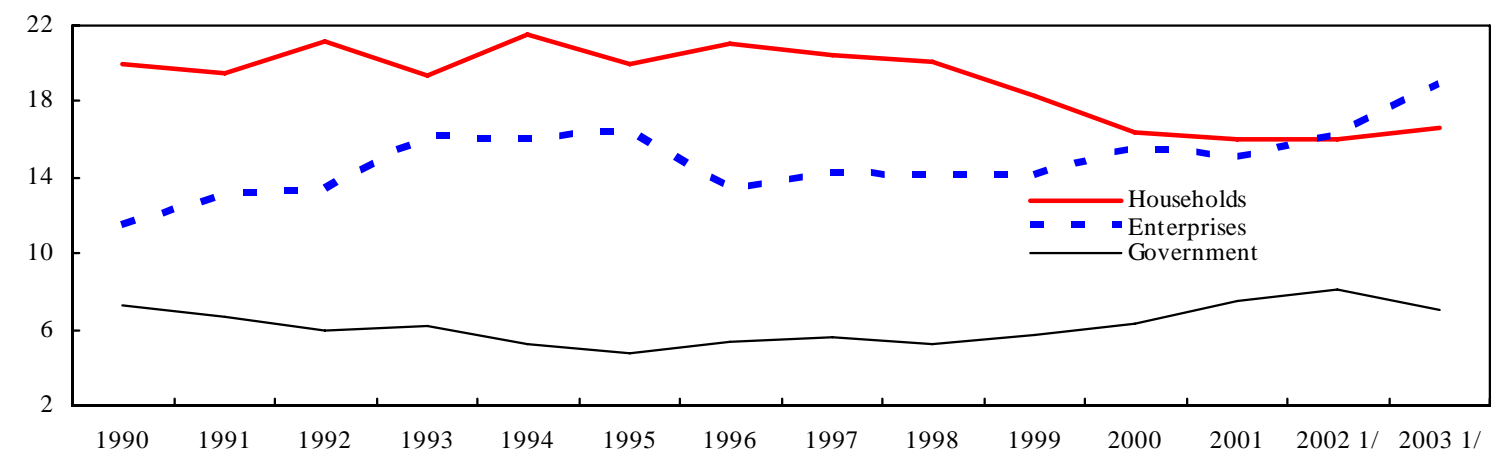

Saving - Investment (percent of GDP)

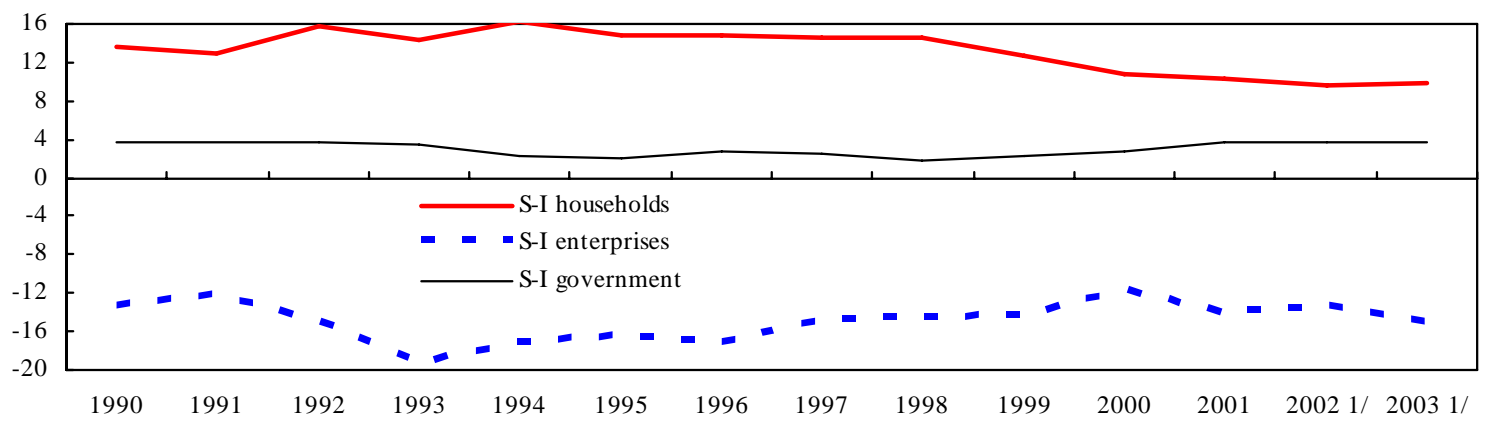

Source: NBS, and staff estimates.

1/ The observations for 2002 and 2003 are estimations (see annex). They are subject to significant uncertainty and may not necessarily be consistent with the "below the line" data on assets. 


\section{Saving and saving-investment balances}

With China's national saving-investment balance (the current account) typically roughly in balance, domestic saving are the predominant financing source of investment. High household saving is only part of the story behind high total saving; the other part is the remarkably high government saving and rising enterprise saving.

Households in China contribute significantly to national saving. The household saving rate (as a share of household disposable income) has been around 25 percent since 2000, having declined from around 30 percent in the mid-1990s.

Data on saving rates can also be obtained from the household survey data. ${ }^{9}$ Our calculations indicate that the saving rate derived from the household survey and from the FoF tables are broadly consistent for recent years (Figure 3), running at around 25 percent. ${ }^{10,11}$ However, for the period prior to 2000 , when the household survey was conducted using a different methodology, it is not consistent. In particular, prior to the mid-1990s, the overall saving rate implied by the household survey was significantly lower than that implied by the FoF data. On the other hand, the overall household saving ratio based on the FoF data is quite close to the data derived by Modigliani and Cao (2004).

Household saving were 16 percent of GDP in 2001, and are estimated to have increased slightly since then (as a ratio of GDP) (Figure 2, middle panel). The balance between saving and investment is in principle available as net financial investment. ${ }^{12}$ This balance came down from 14-16 percent of GDP in the mid-1990s to around 10 percent of GDP in 2000-01 (Figure 2, lower panel). Based on financial assets data, it is estimated to have increased to almost 14 percent in $2002 .{ }^{13}$ The bulk (over 90 percent) of households' net financial investment is in bank saving deposits.

Government saving is remarkably high compared to other countries, and is much higher than suggested by the headline fiscal data. It reached 7.5 percent of GDP in 2001 (it is assumed to have remained roughly at that level in 2002-03). As a result, the government runs a significant saving-investment surplus, which forms an additional financing source. Indeed, in addition to its own investment, the government finances investment via capital transfers to state-owned enterprises in the power, electricity, water, transport, and

\footnotetext{
${ }^{9}$ This survey data is available for urban and rural households separately. It is not straightforward to derive the saving rate for the rural sector, and different researchers have derived different rural saving rates for the same period.

${ }^{10}$ Saving for rural households is calculated by subtracting "living expenditures" from net income.

${ }^{11}$ The data on the total amount of household income and saving implied by the household survey data does not appear to be consistent with that of the flow of funds tables. Potential reasons include: (i) low coverage of high income households; (ii) the valuation of in-kind income; and (iii) the definition of rural income employed in the survey.

${ }^{12}$ Typically a statistical discrepancy appears when the flow information is combined with the "below the line” information on changes in financial assets.

${ }^{13}$ The observations for 2002 and 2003 are estimations (see Annex). They are subject to significant uncertainty and may not necessarily be consistent with the "below the line" data on assets.
} 
Figure 3. China: Household Saving Rate (in percent of disposable income)

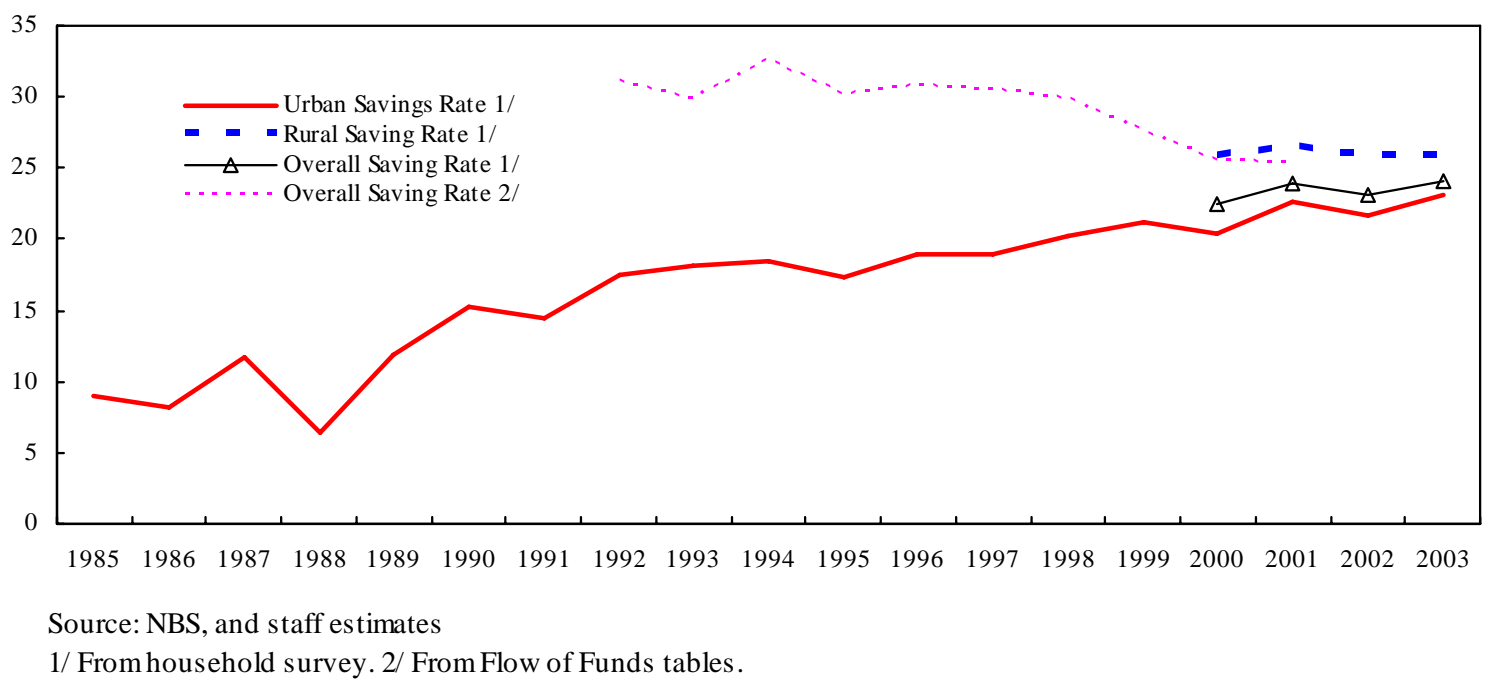

other infrastructure sectors. The transfers were 6.2 percent of GDP in 2001 and are assumed to have remained at roughly that level in 2002-03. Investment by enterprises established by the government financed by capital transfers could be seen as adding to overall public investment.

Enterprise saving from retained earnings constitutes a significant source of saving in China. Since 2000, enterprise saving are roughly as large as household saving. The saving-investment deficit of enterprises was around 14 percent in 2001, which appears to have remained roughly unchanged in 2002-03 (Figure 2, lower panel). Of this, 6.2 percent of GDP was financed by capital transfers from the government. The remaining 8 percent of GDP financing requirement was for 2 percent of GDP covered by a positive "statistical discrepancy"; the remainder is financed by identified external financing. The latter, mainly bank loans and foreign investment, is estimated to have risen to around 10 percent of GDP in 2002-03 (see below).

Based on the above data, China's financial system has been rather effective in channeling financial resources to enterprise investment-an important factor behind China's remarkable growth experience, and in contrast to most developing countries, where banks' assets largely comprise government bonds. In this context, a judgment on the economic efficiency of China's financial system would be more favorable than the more common judgment on financial efficiency.

\section{A closer look at financing of non-financial enterprise investment}

Investment of non-financial enterprises is financed mainly through four sources: own savings, government capital transfers, and bank loans and FDI.

Own saving from retained earnings of non-financial enterprises has increased from around 12.5 percent of GDP in 1996 to almost 15 percent in 2001 and an estimated 18 
percent in 2003 (Figure 4, upper panel)—driven by increasing profitability (Figure 4, upper panel). ${ }^{14}$ In addition to cyclical factors, the increase in profitability is underscored by retrenchment and restructuring of SOEs. First, the importance of private companies has increased. Private companies tend to be more profitable, in the same industry. The share of SOEs and collectively-owned companies in total investment has declined from around 80 percent in the early 1990s to 53 percent in 2003 (NBS, SYB). Second, as part of the restructuring, many SOEs have improved their profitability: the proportion of SOEs making losses has fallen from 25 percent in 1999 to an estimated 8 percent in 2004, and centrally managed SOEs made profits of RMB 400 billion in 2004.

Capital transfers from the government form a significant form of financing (Figure 4, middle and lower panels). The remaining external financing is largely via borrowing from the banking sector and, in recent years, net FDI (Text table below). Gross bank borrowing by enterprises-14 percent of GDP in 2002-has been much higher than net financing by the banking sector-3.6 percent of GDP in 2002-as the latter is moderated by increases in enterprise deposits. Net FDI has been 3-4 percent of GDP in recent years.

The enterprise sector's net external financing was high in the first half of the 1990s: 40 to 60 percent of investment (Figure 4, lower panel). Financed largely via the domestic banking sector, it led to a rapid build up of bank loans (and M2) in that period. It was on a sharp downward trend until 2001, and has picked up in recent years. However, at around 30 percent of enterprise investment, total net external financing remains significantly below the high levels of the first half of the 1990s. ${ }^{15}$ According to the FoF accounts, this is also true for financing via the banking sector (Text table below).

Text table. External Financing of Investment of Non-financial Enterprises (in percent of GDP)

\begin{tabular}{|c|c|c|c|c|c|c|c|c|c|c|c|}
\hline & 1994 & 1995 & 1996 & 1997 & 1998 & 1999 & 2000 & 2001 & 2002 & 2003 & 2004 \\
\hline \multicolumn{12}{|l|}{ Financial Flow of Funds Accounts } \\
\hline Total net external financing & 14.3 & 13.8 & 17.6 & 11.6 & 10.8 & 7.8 & 5.9 & 5.9 & 9.9 & $\ldots$ & $\ldots$ \\
\hline Banking system & 9.4 & 8.9 & 12.2 & 8.9 & 8.0 & 5.0 & 1.7 & 2.4 & 3.6 & $\ldots$ & $\ldots$ \\
\hline Change in loans & 18.8 & 16.6 & 22.2 & 15.2 & 13.0 & 11.1 & 10.4 & 9.7 & 13.8 & $\ldots$ & ... \\
\hline Change in deposits & 9.5 & 7.7 & 9.9 & 6.3 & 4.9 & 6.2 & 8.7 & 7.3 & 10.2 & $\ldots$ & $\ldots$ \\
\hline FDI (net) & $\ldots$ & $\ldots$ & $\ldots$ & 4.9 & 4.3 & 3.7 & 3.5 & 3.2 & 3.7 & $\ldots$ & .. \\
\hline Other (net) & $\ldots$ & $\cdots$ & $\ldots$ & -2.2 & -1.6 & -0.9 & 0.7 & 0.3 & 2.7 & $\ldots$ & $\cdots$ \\
\hline \multicolumn{12}{|l|}{ Financial sector statistics } \\
\hline Domestic bank financing & 6.8 & 9.3 & 7.4 & 8.2 & 8.9 & 6.1 & 4.2 & -5.5 & 10.8 & 13.4 & 8.1 \\
\hline Change in claims 1 / & 16.6 & 16.2 & 14.9 & 16.7 & 13.8 & 11.8 & 11.9 & 2.2 & 18.9 & 24.1 & 17.0 \\
\hline Change in deposits $2 /$ & 9.8 & 6.9 & 7.5 & 8.6 & 4.9 & 5.7 & 7.7 & 7.7 & 8.1 & 10.6 & 8.9 \\
\hline Unadjusted change in claims & 16.6 & 16.2 & 14.9 & 16.7 & 13.8 & 11.8 & 11.9 & 2.2 & 26.2 & 23.1 & 13.4 \\
\hline
\end{tabular}

Sources: NBS and PBC (Flow of Funds), PBC (Monetary statistics) and author's estimates.

1/ Claims to the non-financial sector (including households), from Deposit Money Banks. Attempts were made to adjust for the change in methodology in Jan. 2002 and write off of NPLs in Dec. 2003, Apr. 2004 , and Jun. 2004.

2. Enterprise deposits, from "Sources and Uses of Credit Funds of Financial Institutions".

\footnotetext{
${ }^{14}$ Based on the estimations using the national accounts.

${ }^{15}$ According to the NBS SYB (Table 6.3), the share of total investment (all sectors) funded by domestic loans rose until the early 1990s. It peaked at 27 percent in 1992. Since 1995 it has been around 20 percent.
} 
Figure 4. China, Financing Enterprise Sector Investment, 1992-2003 1/

Enterprise Investment Financing and Profitability

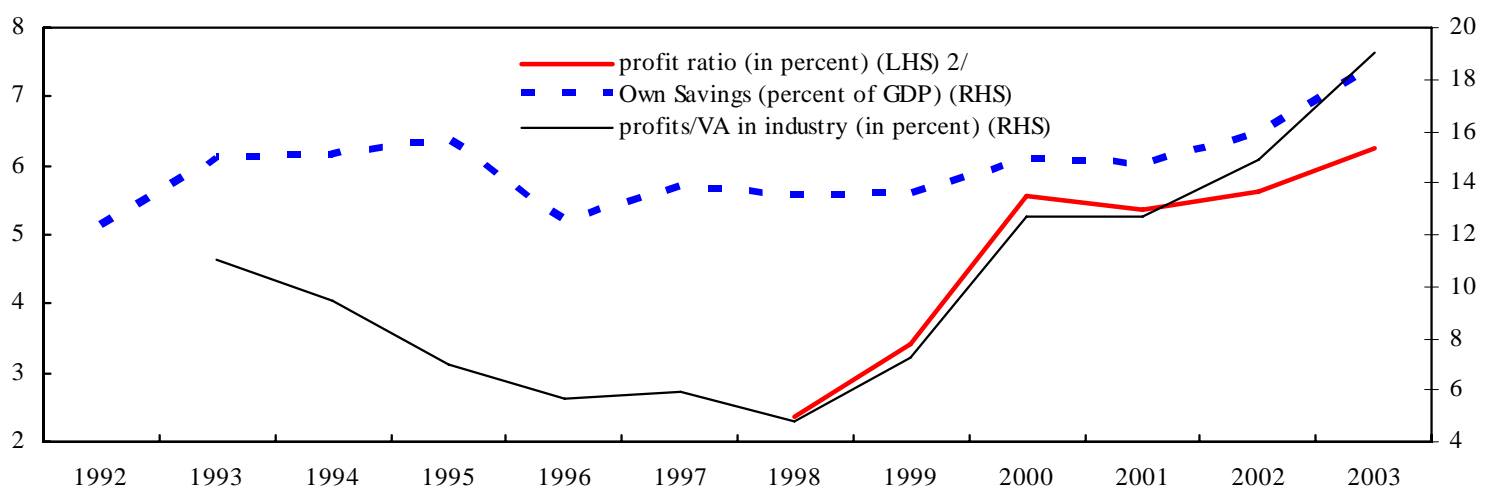

Enterprise Investment Financing (percent of GDP)

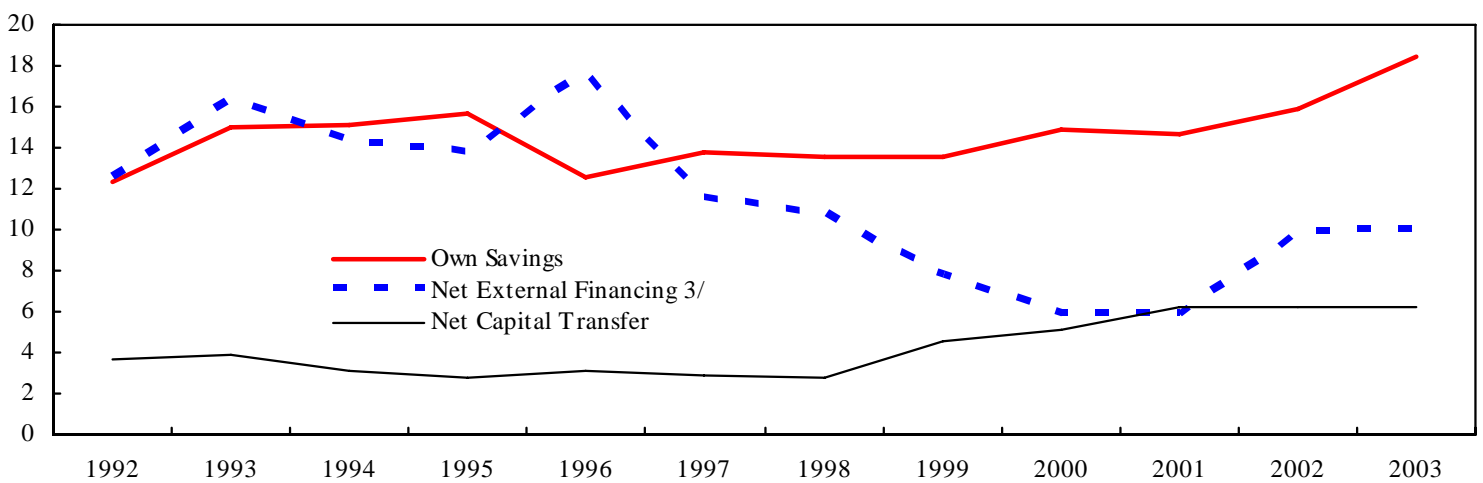

Contributions to Funding Enterprise Investment (percent of total)

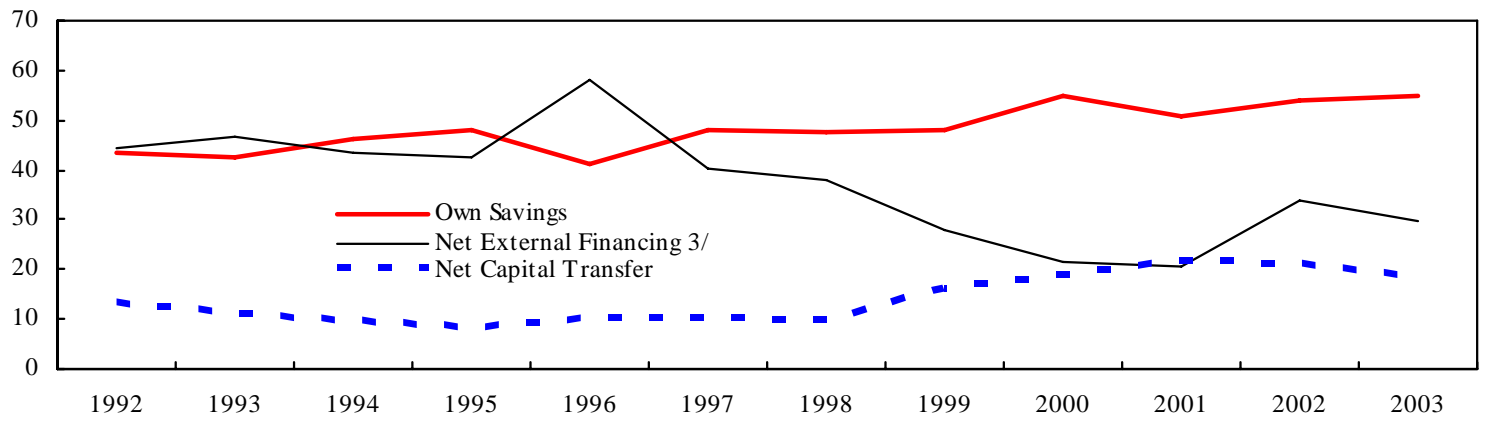

Source: NBS, and staff estimates.

1/ The observations for 2002 and 2003 are estimations (see annex). They are subject to significant uncertainty and may not necessarily be consistent with the "below the line" data on assets. 2/ Profits to costs, in industry.

3/ Including net FDI. 
Financial flows derived from the financial sector statistics (FSS) largely confirm these conclusions. Analysis of the FSS is complicated by methodological changes and, especially in recent years, recapitalization operations. Moreover, the FSS includes lending to households (until very recently this was not distinguished from lending to enterprises). ${ }^{16}$ According to the (adjusted) FSS data, net bank financing to the nonfinancial sector peaked in 2003 at 13.4 percent of GDP, and was 8 percent in 2004 (see Text table above). Given that credit to households has increased rapidly in recent years, the FSS data do also suggest that net bank financing has been a modest share of enterprise investment in recent years.

\section{Investment and Saving in International Comparison}

To put the data on saving and investment in international perspective, it is compared with data for the US, France, Japan, Korea, and Mexico (Table 2). ${ }^{17}$ Total domestic saving was 16 percentage points of GDP higher in China than in the average of these five countries in 2001. This difference is estimated to have increased to 20 percent in 2003.

\section{Households}

Household saving is substantially higher than in the comparator countries. The household saving rate of around 25 percent compares to 16 percent in France, the second highest. ${ }^{18}$ Household disposable income is, surprisingly, not much lower than in France and Japan, as a share of GDP, and even higher than in Korea, although it is much lower than in the US and Mexico. That means that household saving is also relatively high as a ratio of GDP. High household saving typically explains less than one-half of the difference in enterprise sector investment between China and the other countries.

Household capital formation—predominantly residential investment—is at 6.7 percent of GDP in 2003 comparable in size to that in other countries. As a result, the differences in household gross saving rates are largely reflected in differences in net lending of the sector.

\section{Enterprises}

Gross operating surpluses - the source of retained earnings - in China are comparable to those in Japan, but some 9-10 percentage point of GDP higher than in the US, France, and Mexico. Reasons behind these differences include differences in economic structure and dividend policies.

16 Historically roughly comparable, in 2002 banking system net financing of the private sector according to the FSS was significantly higher than banking system net financing of the enterprise sector according to the FoF. Attempts to adjust the FSS credit data for the structural breaks reduce the gap, but it remains sizeable. Interestingly, the accumulated financing during 2001 and 2002 is similar.

${ }^{17}$ The comparison is unfortunately restricted to OECD countries, given the large difficulties obtaining the required data for other countries.

${ }^{18}$ Household saving rates in the US and Japan used to be much higher than they have been recently. 
A key factor behind China's high national and enterprise saving is the large relative size of China's industry. Investment tends to be higher in industry than in other sectors, due to the inherent capital intensity of the processes, which also implies a higher share of value added distributed to capital. These relatively high earnings in industry-if retained-are the core of enterprise saving. Empirical evidence across countries confirms that the investment to GDP ratio tends to be higher in countries with a high share of industry in value added (Figure 5). Within the sample of Figure 5, China has by far the highest shares on both dimensions. In other words, China's very high investment to GDP ratio is consistent with the importance of industry in the economy. ${ }^{19}$ Another key factor is that Chinese companies pay out relatively low dividends. In particular, the SOE sector pays only limited dividends to the shareholder, and non to the state (to which it pays only taxes), although the increase in profitability in recent years has stimulated a policy discussion on the distribution of profits.

Figure 5. China and other Countries: Share of Industry in Value Added and I/Y (2001, unless otherwise indicated) $1 /$

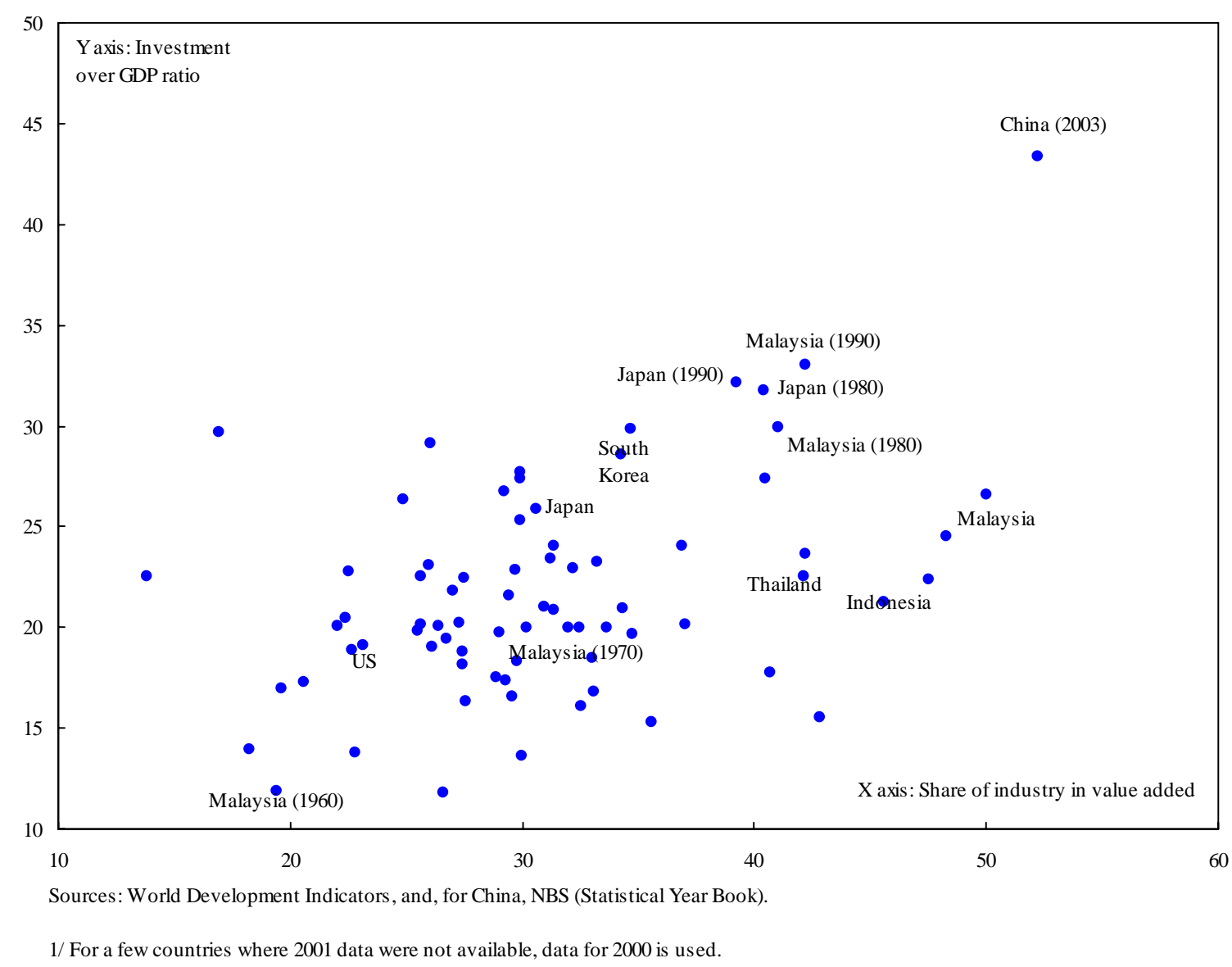

Significant capital transfers to enterprises by the government-6.2 percent of GDP in 2001, and assumed to have remained at roughly that level in 2002-03 — are a unique

\footnotetext{
${ }^{19}$ To the extent that value added in services is underestimated, this would decrease both ratios in the same proportion, leaving China's position vis-à-vis the (imaginary) regression line roughly unchanged.
} 
feature of China. After financing from retained earnings and capital transfers, external financing by the (non-financial and financial) enterprise sector was, at 8.3 percent of GDP (in 2001), high in international comparison (see footnote to Table 2).

\section{Government}

In terms of government revenues as a share of GDP, China is positioned between the US, Japan, and Mexico on the one hand and France and Korea on the other. Government consumption is relatively low in China, particularly compared to France. While there is little difference in direct government investment, large capital transfers to-stateowned - enterprises distinguish China from the other countries. These transfers mean that government saving and government-financed investment (broadly defined) are substantially higher than is suggested by the headline fiscal data.

\section{Conclusions and Policy Implications}

The above analysis has revealed the following points:

- Although discussions on investment and saving traditionally focus on household saving, China's high saving rate is as much driven by high saving of enterprises and the government as by high household saving.

- Investment by households and direct investment by the government has been relatively steady at levels comparable to other countries (around 7 and 3-4 percent of GDP, respectively).

- Investment by the enterprise sector distinguishes China from other countries, and shows most of the variation over time. In recent years, the differential ranged between 11 (Korea) and 20 (US) percentage points of GDP.

- High enterprise investment is financed partly by a large excess of saving over investment of households — channeled by the banking system—and the government- transferred to enterprises.

- But with enterprise own saving having risen as profitability has improved, over one-half is financed by enterprise retained earnings.

- High government saving is a result of a policy favoring government-financed investment over government consumption.

- Reasons for relatively high saving by enterprises include a high share of capital intensive industry in GDP and dividend policies.

These findings lead to three sets of policy-related issues:

\section{1) Financing patterns, and their policy implications}

Systemic risks to the banking sector stemming from China's high investment appear to be smaller than suggested by many observers. It is likely that a significant share of the recent investment is misallocated and some bank-funded investment will never generate the rates of return required to avoid new NPLs. It is also likely that this has significant implications for China's banking system. However, as demonstrated in this paper, the exposure of the banking system to the investment boom is much less than implied by the 
overall investment numbers, and less than at the height of the previous investment cycle - with net external financing including net FDI financing about 30 percent of enterprise investment, compared to 40-60 percent in 1992-96.

By the same token, high and increasing financing of enterprise investment through retained earnings poses its own risks and policy challenges.

- Large-scale re-channeling of profits back in investment by firms makes investment more pro-cyclical and prone to "boom and bust cycles".

- Relatedly, the allocation of capital does not receive the same scrutiny as in the case of channeling via the financial sector, which is likely to affect its efficiency. For instance, although many steel companies have seen large increases in profitability due to high international prices, it may not be optimal to invest these profits in another steel factory. There is also anecdotal evidence of sub-optimal investment by Chinese companies in acquisitions or ventures in other sectors.

- These issues are of particular concern in an environment of low dividend payout and weak corporate governance.

As profitability of SOEs has risen, the distribution of their profits has become a particular issue of debate. Most of the state enterprises have not paid dividends to the shareholder for more than a decade, despite rising profits. This may have been appropriate in times of restructuring. However, to improve the allocation of public resources, transparency, and accountability, a dividend policy for SOEs needs to be developed. Since SASAC is representing the state as an owner, and is not a holding company, the dividends paid out should directly go to the budget. If new capital investments need to be made that require state funding, this should be done through a budget request submitted by SASAC on behalf of the state enterprises. SASAC could play a role in increasing transparency of the management of SOEs by issuing an annual report on the performance of the SOEs under their management. These measures could be supported by auditing of financial accounts by independent auditors to ensure appropriate dividend is paid out. Making the issuance of capital transfers more transparent would also be appropriate.

Strengthening corporate governance, moving to increasing dividend pay-out, and paying more scrutiny to the allocation of capital along these lines would improve the efficiency of capital and tend to shift the trade-off between consumption and investment more towards consumption.

\section{2) Short and medium-term prospects and macroeconomic policy implications}

The current investment to GDP ratio of 45 percent is considered higher than optimal by most observers. The high investment ratio is partly a cyclical phenomenon, and-given the importance of internal financing - investment growth can be expected to fall as profit growth is projected to decline, although by less than one to one. Nevertheless, the structural component of the investment to GDP ratio remains high, and not sustainable in light of long-term saving prospects (see below). The government has recently emphasized the need to improve the quality of growth and increase the role of consumption in the economy (as opposed to investment). In addition to the corporate governance and 
dividend related measures outlined above, what other measures would further these objectives?

- A shift in government spending from investment to spending on health and education ("from construction of physical infrastructure to social infrastructure") would directly reduce national saving and investment. The scope for such a shift is significant, given the high government savings. Expanding the social safety net is also considered by many to reduce private consumption. ${ }^{20}$

- Changes in the policy framework away from the promotion of capital-intensive industry towards labor intensive activities including services would increase the share of labor income in the economy, and thereby the average propensity to consume. This implies adjustments in policies on prices, the financial sector, land, the environment, and labor movement.

Investment has traditionally been correlated strongly with saving, leaving the savinginvestment balance - the external current account—small. To the extent that current trends towards an increasing current account surplus intensify and become problematic, real exchange rate appreciation would reduce the balance. Such an appreciation would reduce profits; it would also reduce investment, but by less than one to one.

\section{3) Longer-term saving prospects and the impact of policy}

Looking further ahead, in addition to the impact of possible policy adjustments as sketched above, several endogenous developments are likely to lead to lower overall saving and investment.

- An eventual moderation of economic growth and demographic changes-with relatively fewer workers-are likely to put significant downward pressure on household saving. Purely for illustration, using coefficients estimated by Modigliani and Cao, and judged by them to be "reasonable" (also in comparison with other studies), a slowdown in long-term GDP growth of 2 percentage points would lead to a decline in the household saving ratio of a whopping 5 percentage points. In addition, the projected increase in the "employment to minor" ratio from around 2.4 now to 2.25 (2.0) in 2030 (2075) would lead to an additional 1.5 (4.0) percentage point decline in the household saving ratio.

- Pension system reform may increase national saving, depending on the degree of funding in the eventual system and household's response to these policy changes. However, pension reform-related upward pressure is unlikely to compensate for the downward pressure coming from a growth slowdown and demographics.

- Further development of financial markets will reduce the number of credit constrained people and small enterprises, and the associated need for saving for anticipating purchases of consumer durables, life-cycle events (such as weddings), and investment.

\footnotetext{
${ }^{20}$ The argument is that currently people increase saving in anticipation of health and education costs. But, on a macro level the payment of these costs reduces saving. Net saving would only increase under certain conditions.
} 


\section{References}

Kraay, A, (2000), Household Saving in China, The World Bank Economic Review, September 2000; 14, 3.

Loayza, N., K. Schmidt-Hebbel, and L. Servén (2000), "What Drives Saving across the World?”, www.worldbank.org/research/projects/savings/whatdriv.htm

Modigliani, F, and Shi Larry Cao (2004), The Chinese Saving Puzzle and the Life-Cycle Hypothesis, Journal of Economic Literature, Vol XLII (March 2004) pp. 145-170.

National Bureau of Statistics, Statistical Yearbook, various issues. 


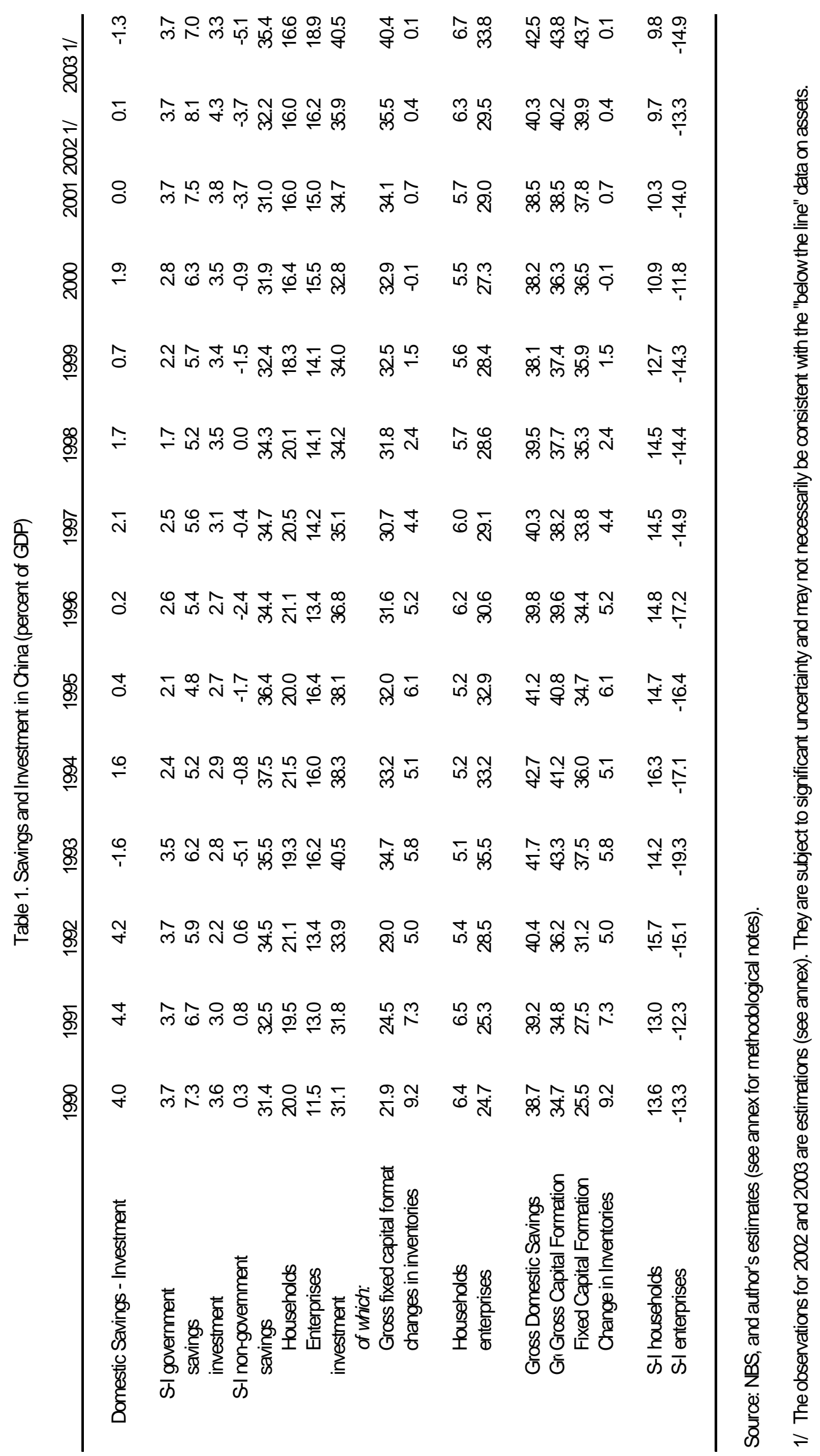


Table 2. Sectoral Saving and Investment: International Comparison

(2002, unless otherwise indicated)

(as percent of GDP)

\begin{tabular}{|c|c|c|c|c|c|c|c|}
\hline \multirow{3}{*}{ Households } & \multicolumn{2}{|c|}{ China } & \multicolumn{2}{|c|}{ United State France } & \multirow[t]{2}{*}{ Japan } & \multirow[t]{2}{*}{ Korea } & \multirow{3}{*}{$\frac{\text { Mexico }}{2001}$} \\
\hline & 2001 & $031 /$ & & & & & \\
\hline & & & & & & & \\
\hline Gross primary income & 62.5 & & 80.6 & 71.5 & 65.1 & 59.3 & 80.5 \\
\hline Net transfers & 0.7 & & -4.9 & -6.1 & 0.3 & 0.9 & 1.4 \\
\hline Gross disposable income & 63.2 & & 75.7 & 65.4 & 65.4 & 60.2 & 81.9 \\
\hline private consumption & 47.2 & & 70.8 & 54.6 & 57.1 & 55.7 & 73.9 \\
\hline Gross savings & 16.0 & 16.6 & $4.83 /$ & 10.8 & 8.2 & 4.5 & 8.0 \\
\hline Gross capital formation & 5.7 & 6.7 & 6.8 & 5.7 & 4.8 & 6.2 & 5.1 \\
\hline Other & 0.6 & & -0.3 & 0.0 & -1.0 & 0.8 & 0.2 \\
\hline Net lending & 10.9 & & -2.3 & 5.2 & 2.4 & -0.9 & 3.1 \\
\hline \multicolumn{8}{|l|}{ Corporations 2I } \\
\hline Gross operating surplus & 15.0 & & 10.3 & 9.5 & 19.4 & 14.8 & 10.6 \\
\hline gross savings & 15.0 & 18.9 & $10.33 /$ & 9.5 & 19.4 & 14.8 & 10.6 \\
\hline net capital transfers received & 6.2 & & 0.0 & 0.5 & 0.6 & 0.5 & 0.2 \\
\hline Gross capital formation & 29.0 & 33.8 & 8.7 & 10.5 & 14.4 & 17.6 & 15.2 \\
\hline Other & -0.5 & & 0.1 & -0.1 & 1.5 & -0.4 & -0.1 \\
\hline Net lending & -8.3 & & 1.7 & -0.5 & 7.2 & -2.7 & -4.5 \\
\hline \multicolumn{8}{|l|}{ Government } \\
\hline Gross disposable income & 20.9 & & 14.4 & 24.2 & 15.5 & 24.7 & 14.7 \\
\hline Final consumption & 13.4 & & 15.2 & 23.9 & 17.7 & 12.9 & 12.5 \\
\hline Savings, gross & 7.5 & 7.0 & -0.9 & 0.3 & -2.2 & 11.7 & 2.2 \\
\hline Net capital transfers & -6.2 & & 0.3 & -0.4 & -0.4 & -1.0 & 1.9 \\
\hline Gross capital formation & 3.8 & 3.3 & 2.5 & 3.1 & 4.7 & 5.3 & 1.8 \\
\hline Other & 1.4 & & -0.1 & -0.1 & -0.7 & 0.1 & -2.2 \\
\hline Net lending & -1.1 & & -3.2 & -3.3 & -7.9 & 5.5 & 0.0 \\
\hline \multicolumn{8}{|l|}{ Total domestic } \\
\hline Gross disposable income & 99.1 & & 100.4 & 99.1 & 100.3 & 99.6 & 107.2 \\
\hline Consumption & 60.6 & & 86.0 & 78.4 & 74.8 & 68.6 & 86.4 \\
\hline Gross Savings & 38.5 & 42.5 & 14.3 & 20.7 & 25.5 & 31.0 & 20.8 \\
\hline Net capital transfers & 0.0 & & 0.3 & 0.2 & 0.3 & -0.5 & 2.1 \\
\hline Gross capital formation & 38.5 & & 18.0 & 19.3 & 23.9 & 29.1 & 22.2 \\
\hline Other & 1.5 & & -0.3 & 0.0 & 0.9 & 1.6 & -3.8 \\
\hline Net lending & 1.5 & & -3.7 & 1.5 & 2.8 & 3.0 & -3.1 \\
\hline Household saving rate & 25.3 & & 6.4 & 16.6 & 12.6 & 7.4 & 9.8 \\
\hline
\end{tabular}

Sources: For China, data from SYB, via CIEC database. For other countries, from OECD Economic Outlook.

The original data for OECD countries on net income and net investment is transformed into gross equivalents by rem consumption of fixed capital--which is not known for China.

1/ Staff estimate: subject to substantial uncertainty.

2/ The total of financial and non-financial enterprises, to ensure comparability with other countries.

In China, in 2001, net lending of the financial sector was -2.4 percent of GDP. 


\section{Annex-methodological notes}

\section{Compilation national accounts presentation of saving and investment (Table 1)}

\section{2-2001:}

Total gross domestic saving (GDS)=

Household saving from the Flow of Funds (FoF)

Government saving (FoF)

Enterprise saving (non-financial plus financial) (FoF)

Enterprise investment $=$

Total gross domestic investment (GDI) (from national accounts; SYB, p66) Household investment (FoF) -

Government investment (FoF)

$(\mathrm{S}-\mathrm{I})$ gross, domestic $=$ GDI - GDS

\section{2-03:}

GDS = GDP - Consumption

Household saving $($ HHS $)=\left(\right.$ HHS $\_1 *$ (Household Survey Household Saving) / (Household Survey Household Saving)

(S-I) government is assumed to remain constant as a share of GDP

Government saving $=(\mathrm{S}-\mathrm{I})$ government + Government investment

Enterprise saving = GDS - HHS - Government saving

Household investment is assumed to grow in line with "investment by individuals" from SYB table 6-2.

Government investment is assumed to grow in line with "investment supported by the budget” from 2004 SYB p. 187.

Enterprise investment $=$

Total gross domestic investment (GDI) (from national accounts; SYB, p66) Household investment - Government investment

$(\mathrm{S}-\mathrm{I})$ gross, domestic $=$ GDI - GDS 